\title{
SEJARAH PENEMPATAN DAN ADAPTASI LINGKUNGAN BARU TRANSMIGRAN JAWA BARAT DI KECAMATAN RASAU JAYA
}

\section{HISTORY OF PLACEMENT AND ADAPTATION OF THE NEW ENVIRONMENT OF WEST JAVA TRANSMIGRANTS IN SUBDISTRICT RASAU JAYA}

\author{
Diah Trismi Harjanti \\ Pendidikan Geografi, FKIP, Universitas Tanjungpura \\ diahtrismiharjanti@fkip.untan.ac.id
}

\begin{abstract}
Abstrak : Ketidakmerataan distribusi penduduk di Indonesia disebabkan oleh terkonsentrasinya penduduk Pulau Jawa membuat pemerintah membuat program perpindahan penduduk yang diberi nama transmigrasi. Jenis transmigrasi yang dilakukan oleh pemerintah Indonesia yaitu transmigrasi umum dan transmigrasi swakarya. Kalimantan Barat yang menjadi daerah tujuan transmigrasi adalah Kecamatan Rasau Jaya Kabupaten Kubu Raya. Dari enam desa di kecamatan Rasau Jaya hanya ada empat desa yang menjadi wilayah penempatan transmigran yaitu Desa Rasau Jaya Satu, Desa Rasau Jaya Dua, Desa Rasau Jaya Tiga dan Desa Bintang Mas. Desa Rasau Jaya Tiga pada tahun 1975-1977 menjadi daerah tujuan transmigrasi yang paling banyak dikarenakan memilki luas lahan daratan yang paling besar diantara desa-desa yang lainnya. Metode yang digunakan adalah deskriptif dengan pendekatan kualitatif dan objek yang diteliti adalah transmigran yang berasal dari Jawa Barat.
\end{abstract}

Kata kunci: Distribusi, Transmigrasi, Transmigran Jawa Barat

\begin{abstract}
The unequal distribution of the population in Indonesia is caused by the concentration of the population of Java, which led the government to create a population movement program called transmigration. The types of transmigration carried out by the Indonesian government are general transmigration and self-employment transmigration. West Borneo, which is the destination for transmigration, is Rasau Jaya District, Kubu Raya Regency. Of the six villages in the Rasau Jaya sub-district, there are only four villages that are the placement areas for transmigrants, namely Rasau Jaya Satu Village, Rasau Jaya Dua Village, Rasau Jaya Tiga Village and Bintang Mas Village. Rasau Jaya Tiga Village in 19751977 became the most transmigration destination area because it had the largest land area among other villages. The method used is descriptive with a qualitative approach and the object under study is the transmigrant who came from West Java.
\end{abstract}

Keywords: Distribution, Transmigration, West Java Transmigrants 


\section{PENDAHULUAN}

Transmigrasi merupakan program pemerintah yang bertujuan pemerataan penduduk.di seluruh Indonesia. Ketidakmerataan distribusi penduduk di Indonesia disebabkan oleh terkonsentrasinya penduduk di satu tempat yaitu Pulau Jawa. Distribusi penduduk yang tidak merata ini menimbulkan beberapa masalah di antaranya, sulitnya mendapatkan pekerjaan, pendapatan penduduk yang rendah, meningkatnya angka pengangguran yang berdampak pada peningkatan angka kriminalitas, tingginya harga jual beli lahan sehingga masyarakat ekonomi rendah kesulitan mendapatkan akses kepemilikan lahan, serta kualitas kehidupan yang kurang baik di tandai dengan rendahnya tingkat pendidikan dan kesehatan yang buruk. Program transmigrasi bermula pada tahun 1905, saat Indonesia masih dibawah kekuasaan Belanda. Pada saat itu nama yang digunakan adalah kolonisasi. Sri Edi Swasono (1986:8) mengungkapkan bahwa, transmigrasi di jaman kolonial Belanda di mulai sejak pertengahan abad ke-19 yang dikenal dengan Ethiesche Politiek. Belanda yang pelit dan sangat hati-hati dalam mengeluarkan uang itu, mulai membuat percobaan. Sebelum program kolonisasi dilaksanakan Pemerintah Belanda menugaskan seorang Assisten Resident bernama H.G Heyting untuk mempelajari kemungkinan-kemungkinan yang dapat terjadi dalam pemindahan penduduk dari Pulau Jawa ke Pulau yang kurang penduduknya dengan tanah yang belum digarap masih sangat luas.

Swasono dan Singarimbun (1986:11) mengemukakan mengenai periode transmigrasi, yang terdiri atas periode awal trasmigrasi, periode tahun 1927-1930, periode tahun 19301935 dan periode sesudah pengakuan kemerdekaan. Periode setelah pengakuan kemerdekaan dilakukan pada tahun 1946 akan tetapi pada tahun tersebut respon penduduk tidak cukup baik. Hal ini dilihat dari tidak adanya tanggapan dari masyarakat mengenai program transmigrasi yang di gagas pemerintah. Pada tahun 1948 Pemerintah Republik Indonesia membentuk suatu panitia untuk mempelajari transmigrasi dari Jawa ke lain-lain daerah. Panitia diketuai oleh Ir. A.H.O. Tambunan, pegawai pada Kementrian Pembagunan dan Pemuda. Kepanitian ini bersifat interdepartemental. Sebagaimana mestinya dalam masa revolusi, sering muncul cita-cita muluk dan rencana abstrak. Namun, rencana transmigrasi tersebut dapat direalisasi sesudah pengakuan kedaulatan pada tahun 1948.

Pada tahun 1948 nama yang dipakai untuk program perpindahan penduduk ini tidak lagi kolonisasi namun dirubah menjadi transmigrasi. Hal ini bertujuan untuk menghilangkan bayang-bayang pemerintahan Belanda yang kejam. Juga dilakukan perbaikan-perbaikan Jurnal Swadesi, Volume II Nomor 1 (Mei) 2021 
sistem pengelolaan antara lain dari tata cara pemindahan, sarana dan prasarana yang didapat di daerah tujuan, pelayanan yang diberikan pemerintah kepada para transmigran, serta jaminan kehidupan yang lebih baik di daerah tujuan transmgrasi. Jaminan yang diberikan salah satunya adalah setiap KK diberikan unit rumah layak huni serta sawah/ladang sebagai tempat untuk mencari penghidupan.

Karl J.Pelzer dalam Kartomo, (1986:231) yang menyebutkan transmigrasi sebagai pemecahan masalah penduduk dengan memindahkan penduduk dari pulau jawa menuju ke luar pulau jawa. Adapun tujuan dari transmigrasi adalah sebagi upaya mendorong pertumbuhan ekonomi di daerah tujuan transmigrasi, yang didukung oleh sumberdaya manusia yang secara sukarela mau dan mampu untuk menetap di daerah kawasan transmigrasi yang telah ditetapkan oleh pemerintah.

Faktor-faktor penarik dan pendorong dari program transmigrasi ini yang menyebabkan para calon transmigran, mau dan bersedia mengikuti program transmigrasi. Hal ini seperti dikutip dalam Harjanti (2009:37-41) bahwa yang menjadi faktor pendorong dari transmigran melakukan transmigrasi adalah kondisi wilayah dan kehidupan sosial di daerah asal yang kurang baik. Hal ini dilihat dari makin berkurangnya sumber-sumber kehidupan, sempitnya lahan garapan, dan lahan pekerjaan serta terbatasnya tingkat pendidikan. Sedangkan faktor yang menarik para transmigran antara lain; kepemilikan lahan yang luas di daerah transmigrasi, mendapatkan pelatihan untuk menambah kecakapan hidup serta adanya harapan di wilayah yang baru kondisi sosial ekonomi akan membaik.

Di Indonesia ada bermacam-macam jenis transmigrasi. Berdasarkan jenis bantuan yang diberikan oleh pemerintah, trasnmigrasi dapat dibedakan menjadi dua jenis yaitu transmigrasi umum dan transmigrasi swakarya. Menurut Harjanti (2009:29) transmigrasi umum adalah transmigrasi yang pembiayaannya dari pemberangkatan sampai penempatan dalam jangka waktu tertentu biaya sebagian besar ditanggung oleh pemerintah pusat sedangkan transmigrasi swakarya transmigrasi yang diselenggarakan oleh departemen transmigrasi dengan jaminan hidup beberapa tahun, selanjutnya diberikan tanah kepada transmigran untuk dikerjakan.

Wilayah Kalimantan, khususnya Kalimantan Barat daerah yang menjadi salah satu tujuan transmigrasi adalah Kecamatan Rasau Jaya Kabupaten Kubu Raya (dulunya masuk menjadi bagian dari kecamatan Sungai Kakap Kabupaten Pontianak (saat ini Kabupaten Pontianak berubah nama menjadi Kabupaten Mempawah)). Wilayah Kecamatan Rasau Jaya Jurnal Swadesi, Volume II Nomor 1 (Mei) 2021 
merupakan salah satu kecamatan yang ditetapkan pemerintah pusat sebagai bagian dari daerah tujuan transmigrasi. Berikut ini wilayah Kecamatan Rasau Jaya yang bisa dilihat pada gambar 1 .

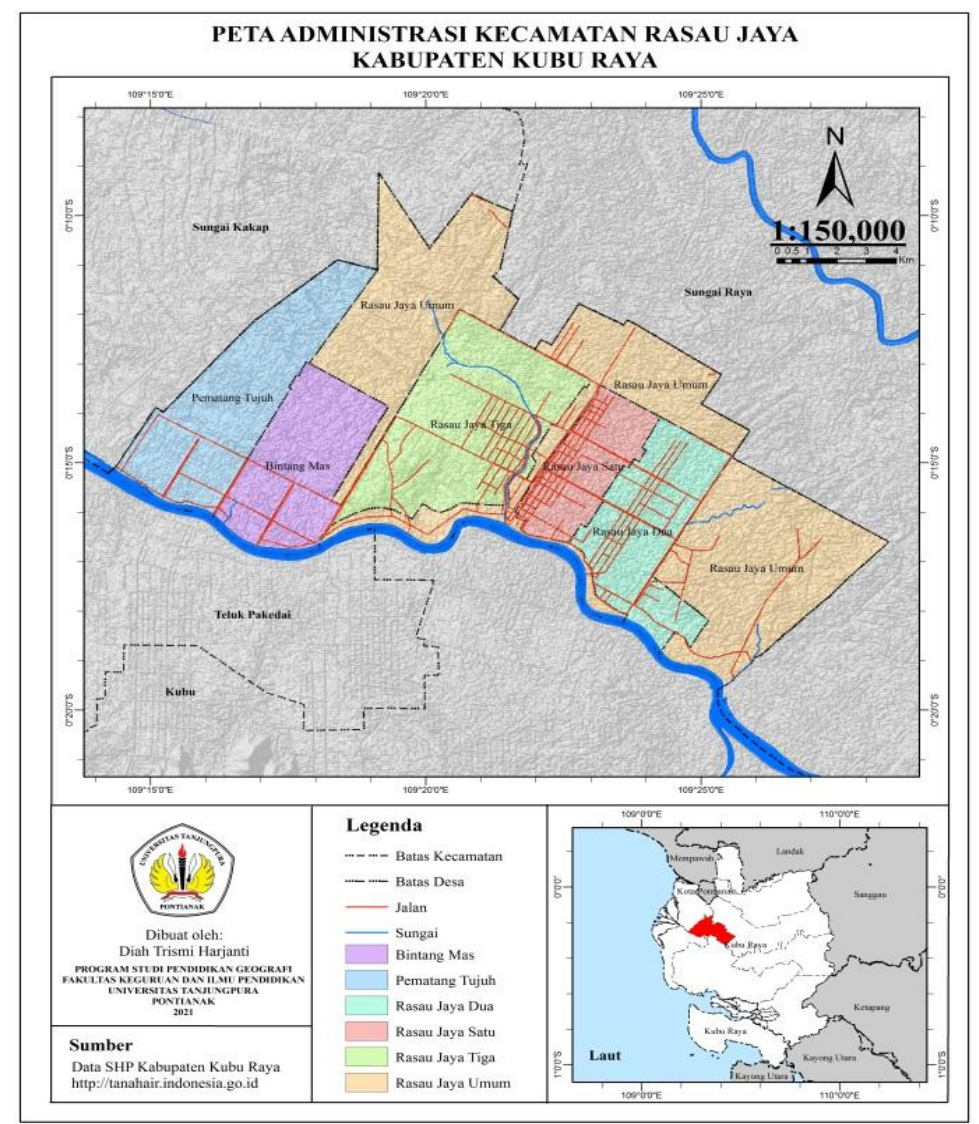

Gambar 1. Peta administrasi Kecamatan Rasau Jaya Kabupaten Kubu Raya (Sumber : Hasil Olahan)

Dari gambar dapat dilihat Kecamatan Rasau Jaya terdiri dari 6 desa yaitu, Desa Rasau Jaya Umum, Desa Rasau Jaya Satu, Desa Rasau Jaya Dua, Desa Rasau Jaya Tiga, Desa Bintang Mas, dan Desa Pematang Tujuh. Akan tetapi, dari keeman desa yang menjadi dari daerah penempatan transmigrasi hanya di empat desa yaitu Desa Rasau Jaya Satu, Desa Rasau Jaya Dua, Desa Rasau Jaya Tiga dan Desa Bintang Mas. Dari empat desa tersebut Desa Rasau Jaya Tiga menjadi desa yang paling banyak ditargetkan kedatangan transmigrasi yaitu sebanyak 641 KK atau 2.564 Jiwa dari periode kedatangan tahun 1975-1977. Lebih lengkapnya dapat dilihat pada tabel 1 . 
Tabel 1. Periodisasi Kedatangan Para Transmigran Datang Di Kecamatan Rasau Jaya

\begin{tabular}{|c|c|c|c|c|c|}
\hline \multirow[t]{2}{*}{ No. } & \multirow[t]{2}{*}{ Lokasi } & \multirow[t]{2}{*}{ Target } & \multicolumn{2}{|c|}{ Realisasi Penempatan } & \multirow{2}{*}{$\begin{array}{c}\text { Tahun / periodisasi kedatangan para } \\
\text { Transmigran datang di Kecamatan } \\
\text { Rasau Jaya }\end{array}$} \\
\hline & & & KK & Jiwa & \\
\hline 1 & Rasau Jaya Satu & 444 & 444 & 2.053 & 1971-1975 \\
\hline 2 & Rasau Jaya Dua & 506 & 506 & 2.141 & $1972-1975$ \\
\hline 3 & Rasau Jaya Tiga & 641 & 641 & 2.564 & 1975-1977 \\
\hline \multirow[t]{2}{*}{4} & Bintang Ms & 200 & 200 & 858 & $1977-1978$ \\
\hline & & 100 & 100 & 377 & 1993-1994 \\
\hline
\end{tabular}

Sumber: Dinas Transmigrasi Kalimantan Barat, 2021

Berdasarkan tabel diatas Desa Rasau Jaya Tiga pada tahun 1975-1977 menjadi daerah tujuan transmigrasi yang paling banyak dikarenakan memilki luas lahan daratan yang paling besar diantara desa-desa yang lainnya di Kecamatan Rasau Jaya (dapat dilihat pada gambar 1). Untuk daerah asalnya yang ditempatkan di Desa Rasau Jaya Tiga berasal dari DKI Jakarta, Jawa Timur, Jawa Tengah, dan Jawa Barat. Akan tetapi sebagian besar transmigran yang ada di Desa Rasau Jaya Tiga adalah transmigran asal Jawa Tengah dan Jawa Timur. Sedangkan untuk DKI Jakarta hanya 50 KK dan Jawa Barat hanya 100 KK.

Pada penelitian ini transmigran yang berasal dari Jawa Barat merupakan objek kajian yang diteliti. Kajian yang diteliti salah satunya adalah cara beradaptasi transmigran dengan wilayah barunya khususnya wilayah Desa Rasau Jaya Tiga. Cara beradaptasi dan bertahan hidup serta mempertahankan kebudayaan yang di bawa dari daerah asal hingga ke wilayah yang baru merupakan bentuk eksistensi para transmigran asal Jawa Barat dalam mempertahankan hidup di wilayah transmigrasi.

\section{METODE}

Pada penelitian ini metode yang digunakan adalah deskrptif melalui pendekatan kualitatif. Metode dan pendekatan ini memiliki ciri mendalam dan menusuk. Hal ini seperti dikemukakan oleh Bungin (2007:69) "metode deskriptif kualitatif menganut paham fenomenologis dan postpositivisme, sehingga fenomena yang dikaji memusat dan mendalam". Sedangkan menurut Nazir, 2005:54 "Metode deskriptif adalah suatu metode dalam meneliti status sekelompok manusia, suatu objek, suatu set kondisi, suatu sistem pemikiran, ataupun suatu kelas peristiwa masa sekarang" dan pendapat ini diperkuat oleh Whitney (dalam Nazir, 2005:54 ), metode deskriptif adalah pencarian fakta dengan 
interpretasi yang tepat. Lebih lanjut Nazir memaparkan bahwa tujuan dari penelitian deskriptif adalah untuk membuat deskripsi, gambaran secara sistematis, faktual dan akurat, mengenai fakta-fakta, sifat-sifat serta hubungan antar fenomena yang diselidiki.

Pada metode deskriptif melalui pendekatan kualitatif cara memperoleh sumber data dan penentuan unit analisis penelitian menjadi sesuatu yang penting yang harus dilakukan oleh peneliti. Sumber data di ambil dari informan yang diwawancarai sedangkan penentuan unit analisis ditentukan dari fokus penelitian yang dilakukan oleh peneliti. Data-data yang dikumpulkan dari para informan akan di lalukan reduksi data sehingga menjadi satu kesatuan data yang saling berkaitan dan membentuk triangulasi data.

Lokasi yang menjadi objek penelitian adalah Desa Rasau Jaya Tiga Kecamatan Kubu Raya. Informan yang dilakukan wawancara adalah transmigran asal daerah Jawa Barat yang ditempatkan di Desa Rasau Jaya Tiga. Untuk lebih jelasnya dapat dilihat pada gambar 2.

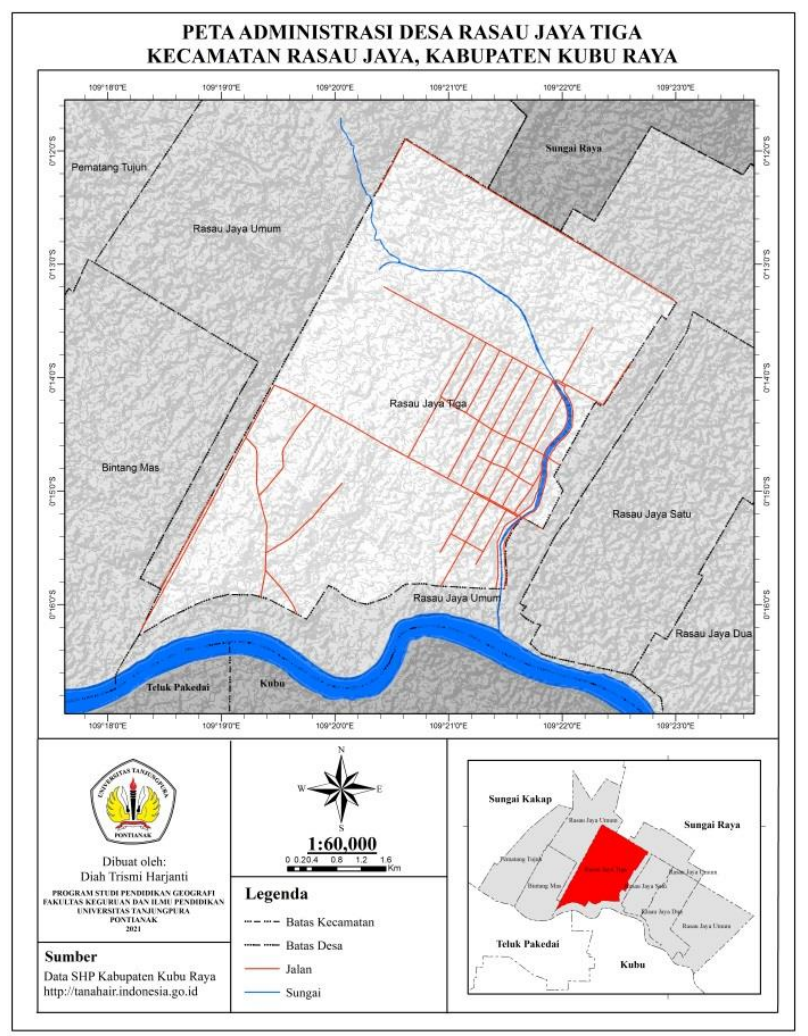

Gambar 2. Peta lokasi penelitian di wilayah Desa Rasau Jaya Tiga Kecamatan Rasau Jaya (Sumber : Data Olahan)

\section{HASIL DAN PEMBAHASAN}

Transmigrasi merupakan perpindahan penduduk secara sukarela untuk meningkatkan kesejahteraan dan untuk menetap di daerah kawasan transmigrasi yang diselenggarakan oleh 
pemerintah. Perperpindahan penduduk diarahkan sebagai upaya untuk mendorong pertumbuhan ekonomi daerah tujuan transmigrasi. Dengan keterampilan yang dimiliki terutama kemampuan bercocok tanam para transmigran diharapkan terjadi proses pembelajaran dan beradaptasi antara penduduk setempat dengan para transmigrans. Transmigrasi tidak lagi menjadi program pemindahan penduduk, tetapi menjadi upaya untuk pengembangan wilayah. Metode ini tidak lagi terpusat dan top down dari jakarta namun berdasarkan kerja sama antar daerah pengirim dengan transmigrasi-transmigrasi lokal.

Penduduk setempt semakin diberi kesempatam besar untuk menjadi Transmigrasi Penduduk Setempat (TPS) proporsi hingga 50:50 dengan Transmigrasi Penduduk Asal (TPA). Karena sebagian besar penduduk terfokus di suatu wilayah seperti kota besar atau pulau yang memiliki kesempatan kerja atau kesempatan hidup besar. Sehingga agar di kota itu pulau yang dianggap maju tersebut tidak terjadi kepadatan penduduk yang tinggi maka perlu dilakukan penyebaran penduduk dengan cara transmigrasi. Perpindahan penduduk umumnya bagi masyarakat mempunyai keterbatasan lahan atau tidak memiliki aset yang memadai. Dengan demikian diharapkan di lokasi yang baru para transmigrans dapat mengelola lahan dan dapat bekerja sama dengan masyarakat lokal sehingga kesejahteraan para transmigran akan meningkat. Wilayah yang menjadi tujuan transmigrasi diantaranya wilayah Sumatera, Kalimantan, dan Papua. Akan tetapi, menurut Swasono dan Singarimbun (1986:43), transmigrasi umum yang diatur pemerintah dimulai di masa Hindia Belanda pada tahun 1936 dengan memukimkan orang jawa di daerah rawa sebelah hilir Banjarmasin dengan penggalian Anjir Tamban dari Barito menuju Sungai Kapuas-Murung. Pada tahun 1938 pemerintah Hindia Belanda mulai memukimkan orang Madura di bukit-bukit andesit sebelah hulu dan utara Riam Kiwa cabang sungai Martapura anak Sungai Barito. Sehingga sampai saat ini Pulau Kalimantan masih menjadi daerah tujuan transmigrasi terbesar.

Pulau Kalimantan memiliki luas $750.000 \mathrm{~km} 2$, sementara itu yang termasuk NKRI seluas 500.000 sehingga 2/3 pulau Kalimantan milik Indonesia. Keistimewaan Pulau Kalimantan merupakan pulau yang kaya akan sumber daya alam. Banyak ditemukan pertambangan emas, intan, antimon, merkuri, bauksit, minyak bumi, gas alam, dan batu bara. Selain barang tambang banyak juga ditemukan hasil hutan berupa beberapa jenis kayu, antara lain ulin, meranti, ramin, kamper, kuku, gelam, kruing, bangkirai, dan belian. Pulau Kalimantan sebagai penghasil tambang dan sumber daya hutan, juga memiliki hasil pertanian dan perkebunan yang melimpah seperti karet, kelapa sawit, lada, duren, cempedak, rotan, dan Jurnal Swadesi, Volume II Nomor 1 (Mei) 2021 
jeruk. Pulau Kalimantan memiliki beberapa keistimewaan diantaranya terdapat sungai-sungai besar seperti sungai Barito, Mahakam, Kayan, Kapuas, Kahayan, Mantayan, Pawan, Lamandau, Pembuang. Sungai Kapuas dan Sungai Sambas di Kalimantan Barat memiliki potensi irigasi yang baik namun, belum dimanfaatkan dengan baik. Air sungai yang ada di Kalimantan hampir seluruhnya masih mengalir ke laut tanpa dimanfaatkan dengan baik.

\section{Identitas Informan}

Pada penelitian ini, proses pengambilan data primer dilakukan pada 29 Maret 2021, objek penelitian adalah informan yang berjumlah 5 orang. Informan pertama adalah Bapak Aang (selanjutnya dinotasikan dengan inisial A), seorang transmigran asal Provinsi Jawa Barat yang mengikuti program transmigrasi gelombang 1 yang diberangkatkan pada tahun 1971. Informan kedua adalah Ibu Asih (selanjutnya dinotasikan dengan inisial AS), istri dari Bapak A yang juga berasal dari provinsi Jawa Barat mengikuti program transmigrasi beserta orang tuanya pada gelombang pertama. Informan ketiga adalah Bapak Yayat (selanjutnya dinotasikan dengan inisisal Y) transmigran asal Provinsi Jawa Barat yang mengikuti program transmigrasi pada gelombang 6 yaitu tahun 1977. Informan keempat adalah Ibu Komariah (selanjutnya dinotasikan dengan inisial K), Istri dari Bapak Y yang juga berasal dari Provinsi Jawa Barat, mengikuti program transmigrasi bersama orangtuanya pada gelombang 6 yaitu tahun 1977.

\section{Tipe dan Penempatan Blok Transmigrasi}

Keikutsertaan peserta transmigrasi asal Jawa Barat ketika itu dibagi menjadi 2 jenis yaitu transmigrasi Swakarsa (spontan/mandiri atas dasar keinginan sendiri), dan Transmigrasi Swakarya/Umum melalui hasil pendataan yang dilakukan oleh pemerintah di daerah asal (dalam hal ini Depertemen Transmigrasi Provinsi Jawa Barat). Hasil wawancara dengan keempat informan utama menunjukkan perbedaan tipologi pada program transmigrasi yang diikutinya, seperti ditunjukkan pada tabel berikut ini:

Tabel 2 Tipe Transmigrasi Dan Alasan Mengikuti Program Transmigrasi

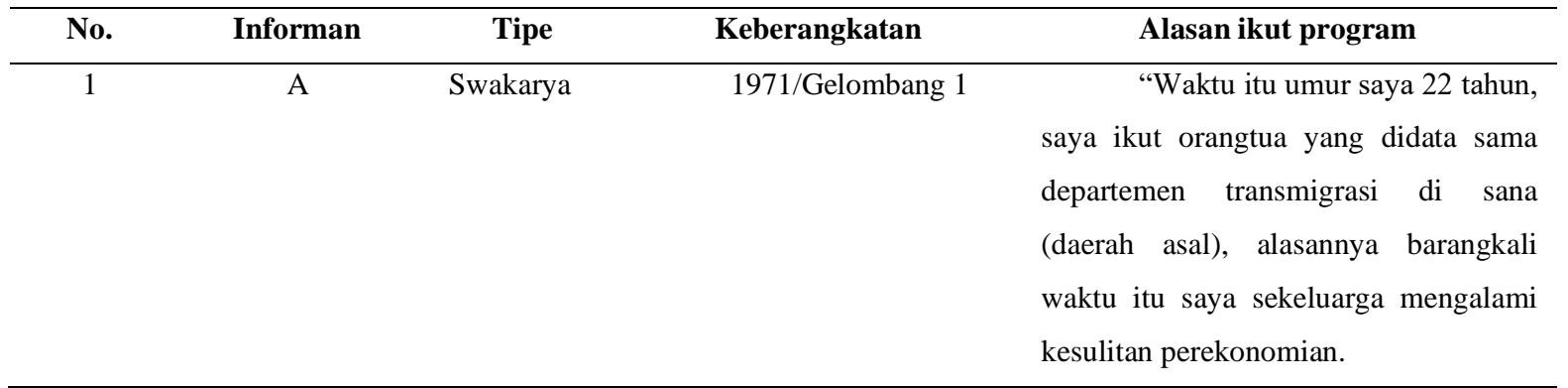




\begin{tabular}{|c|c|c|c|c|}
\hline 2 & AS & Swakarya & 1971/Gelombang 1 & $\begin{array}{l}\text { "Ya ikut sama orang tua saja, } \\
\text { waktu itu saya agak kurang paham juga } \\
\text { sih, soalnya masih SD, tapi dari cerita } \\
\text { orang tua yang saya tau, di kampong } \\
\text { (daerah asal) dulu, serba susah, ga } \\
\text { punya sawah" }\end{array}$ \\
\hline 3 & $\mathrm{Y}$ & Umum & 1977/Gelombang 6 & $\begin{array}{l}\text { "Awalnya sih disuruh sama } \\
\text { orang tua, terus mendaftarkan diri, } \\
\text { diberikan pelatihan dan diberangkatkan } \\
\text { ke sini (Rasau jaya), waktu itu saya } \\
\text { belum menikah, umur saya } 22 \text { tahun, } \\
\text { dapat jodohnya juga di sini" }\end{array}$ \\
\hline 4 & $\mathrm{~K}$ & Swakarya & 1977/Gelombang 6 & $\begin{array}{l}\text { "Saya kurang paham juga sih, } \\
\text { ketika berangkat tahun } 1977 \text { itu ikut } \\
\text { sama orang tua, saya sendiri masih } \\
\text { remaja ketika itu, mungkin alasan oran } \\
\text { tua ya perbaikan nasib" }\end{array}$ \\
\hline
\end{tabular}

Sumber: Hasil Penelitian, 2021

Berdasarkan tabel di atas dapat diketahui tipe dan alasan informan mengikuti program transmigrasi, 3 dari 4 informan mengikuti tipe transmigrasi umum/swakarya melalui pendataan departemen transmigrasi di daerah asal. Selain itu 3 dari 4 informan menyampaikan alasan ekonomi yang mendorong keikutsertaannya pada program transmigrasi.

Adapun penempatan blok transmigrasi untuk transmigran asal provinsi jawa barat ketika itu adalah TR 5 (Tersier 5, sekarang diberi nama jalan rajawali) Desa Rasau Jaya Tiga (Dulu bernama Unit Tiga) Kecamatan Sungai Kakap yang telah mengalami pemekaran menjadi Kecamatan Rasau Jaya seiring pemekaran Kabupaten Kubu Raya yang lepas dari Kabupaten Pontianak (Sekarang kabupaten Mempawah). Blok TR 5 ditempati transmigran asal Provinsi Jawa Barat dan Provinsi DKI Jakarta.

\section{Adaptasi Lingkungan dan Budaya Baru}

Keberangkatan transmigran dari daerah asal ke daerah tujuan dibedakan berdasarkan gelombang pemberangkatan. Bapak A menyebutkan keberangkatan transmigran pada gelombang 1 melalui jalur laut, hal ini ditegaskan pula oleh Ibu AS, "Ya, waktu itu transmigran diberangkatkan dari Jawa pake kapal laut, lama di perjalanan kurang lebih 3 hari 3 malam, beda dengan gelombang berikutnya udah enak pake pesawat". Berbeda dengan 
keberangkatan gelombang 1, Bapak Y dan Ibu K tidak menggunakan jalur kapal laut, seperti yang diutarakan oleh Ibu K, "Kalo saya di gelombang 6 tahun 1977, udah pake hercules , ga kayak (red:seperti) gelombang awal yang pake kapal laut, lebih nyaman karena lebih cepat".

Kondisi penempatan awal transmigran di blok TR 5 sangat sulit baik secara geografis maupun secara social. Adapun persepsi perbedaan lingkungan fisik yang dirasakan transmigran dapat dilihat pada tabel berikut ini:

Tabel 3. Perbedaan lingkungan Fisik

\begin{tabular}{|c|c|c|c|c|c|}
\hline No & Informan & Iklim & Air Bersih & Topografi & Lahan Pertanian \\
\hline 1 & A & $\begin{array}{l}\text { "Beda jauh, } \\
\text { di tempat asal sih } \\
\text { nyaman, ga sepanas } \\
\text { disini, curah hujan } \\
\text { juga ga sesering } \\
\text { seperti disini" }\end{array}$ & $\begin{array}{l}\text { "kalau disini } \\
\text { harus nampung air } \\
\text { hujan untuk minum, } \\
\text { beda dengan di jawa, } \\
\text { ada mata air dari } \\
\text { gunung-gunung" }\end{array}$ & $\begin{array}{l}\text { "Disini } \\
\text { dataran rendah, tidak } \\
\text { ada gunung-gunung } \\
\text { seperti di tempat } \\
\text { asal saya" }\end{array}$ & $\begin{array}{l}\text { "Awalnya sangat } \\
\text { sulit membuka lahan } \\
\text { pertanian, di hutan } \\
\text { berawa, apalagi dengan } \\
\text { alat-alat sederhana, tapi } \\
\text { yam au tidak mau, ga ada } \\
\text { pilihan" }\end{array}$ \\
\hline 2 & AS & $\begin{array}{l}\text { "Lupa saya, } \\
\text { gimana kondisi di } \\
\text { tempat asal, mungkin } \\
\text { lebih sejuk, maklum } \\
\text { waktu berangkat } \\
\text { transmigrasi masih } \\
\text { belum mengerti" }\end{array}$ & $\begin{array}{l}\text { "dulu pas awal } \\
\text { transmigrasi coba } \\
\text { minum air gambut", } \\
\text { tidak enak, tidak layak } \\
\text { juga, pantesan sama } \\
\text { pemerintah diberi } \\
\text { bantuan gentong- } \\
\text { gentong air, rupanya } \\
\text { minum itu harus } \\
\text { nampung air hujan" }\end{array}$ & $\begin{array}{l}\text { "Awal } \\
\text { datang rasau itu } \\
\text { masih } \\
\text { belantara, tapi } \\
\text { tanahnya gambut, } \\
\text { basah, berair, dan } \\
\text { banyak nyamuk" }\end{array}$ & $\begin{array}{l}\text { "Dulu yang } \\
\text { pertama kali mengolah } \\
\text { lahan pertanian itu orang } \\
\text { tua saya, saya hanya } \\
\text { melanjutkan ketika orang } \\
\text { tua sudah tidak mampu, } \\
\text { dan ketika saya } \\
\text { melanjutkan sudah enak" }\end{array}$ \\
\hline 3 & $\mathrm{Y}$ & $\begin{array}{l}\text { "disini lebih } \\
\text { panas dan lebih } \\
\text { lembab, } \\
\text { tanahnya berair ikut } \\
\text { nguap juga waktu } \\
\text { kena } \\
\text { matahari" }\end{array}$ & $\begin{array}{l}\text { "dari awal } \\
\text { pelatihan sudah } \\
\text { dikasih tau SPAH } \\
\text { (Sistem pemanenan air } \\
\text { hujan) } \\
\text { pemerintah, meskipun } \\
\text { ada juga sumur, tapi } \\
\text { fungsinya hanya untuk } \\
\text { mandi dan mencuci } \\
\text { pakaian }\end{array}$ & $\begin{array}{l}\text { "Daerah sini } \\
\text { landai, saya yang } \\
\text { biasa lihat bukit } \\
\text { disini ga ada" }\end{array}$ & $\begin{array}{l}\text { Tidak } \\
\text { yang biasa saya tanam di } \\
\text { Jawa itu bisa tumbuh } \\
\text { disini karena tanahnya } \\
\text { sangat asam, kadang } \\
\text { perlu dibakar dulu atau } \\
\text { minimal diberi kaptan } \\
\text { (kapur pertanian) }\end{array}$ \\
\hline 4 & $\mathrm{~K}$ & $\begin{array}{l}\text { "Sebetulnya } \\
\text { berat, apalagi kalau }\end{array}$ & $\begin{array}{r}\text { Air parit } \\
\text { sebetulnya bersih, tapi }\end{array}$ & $\begin{array}{r}\text { "Rasau itu } \\
\text { tanahnya }\end{array}$ & $\begin{array}{l}\text { "Perlu kesabaran } \\
\text { dalam bercocok tanam, }\end{array}$ \\
\hline
\end{tabular}

\footnotetext{
${ }^{1}$ Tanah Organik (Organosol), bersifat sangat asam ( $\mathrm{pH}$ rendah) hampir tidak memiliki kandungan mineral yang dibutuhkan untuk budidaya tanaman pangan dan tanaman hortikultura
} 


$\begin{array}{lrlrlrl}\text { sedang } & \text { kemarau } & \text { tidak } \text { untuk jadi } & \text { gambut, } & \text { terus } & \text { ya itu dia artinya nanam } \\ \text { panjang, } & \text { sering } & \text { sumber air minum, banyak saluran yang cocok saja. Disini } \\ \text { kejadian karhutla } & \text { untuk minum tetap } & \text { buatan (Parit) yang juga dulu banyak } \\ \text { juga, udara jadi ga } & \text { nampung air hujan, } & \text { nyambung ke Sungai binatang buas" } & \\ \text { enak" } & & \text { harus punya gentong } & \text { Kapuas, saluran } & \\ & \text { banyak, antisipasi } & \text { buatan itu dikasih } & \\ & \text { musim } \quad \text { kemarau } & \text { nama Sekunder dan } & \\ & \text { panjang" } & & \text { Tersier" }\end{array}$

Sumber: Hasil Penelitian, 2021

Berdasarkan tabel di atas, dapat diketahui terdapat perbedaan signifikan dari kondisi lingkungan fisik di daerah asal dan daerah tujuan trasnmigrasi. Transmigran dituntut untuk beradaptasi sedemikian rupa menghadapi lingkungan baru yang sama sekali berbeda dengan daerah asalnya. Perbedaan lingkungan fisik itu berupa kondisi iklim tropika basah dengan temperature yang tinggi dan curah hujan yang tinggi pula. Sumber air bersih untuk minum juga berasal dari air hujan yang tidak mengandung mineral seperti air tanah. Secara topografi Rasau Jaya termasuk bagian dari delta Kapuas dengan kandungan tanah gambut (organic soil) yang tebal sehingga menyulitkan untuk dikelola menjadi lahan pertanian produktif seperti di daerah asal transmigran.

Kondisi sosial masyarakat asli dan pendatang juga mengharuskan transmigran asal Provinsi Jawa Barat ini beradaptasi dengan lingkungan baru.

Tabel 4. Pelestarian Budaya Sunda dan Adaptasi Budaya Baru

\begin{tabular}{|c|c|c|c|}
\hline No. & Informan & Pelestarian Budaya Sunda & Adaptasi Budaya Baru \\
\hline 1 & A & $\begin{array}{l}\text { "Tidak pernah lagi, karena saya disini } \\
\text { minoritas" }\end{array}$ & $\begin{array}{l}\text { "Terutama dari sisi bahasa, karena tidak } \\
\text { jarang terjadi perkelahian karena } \\
\text { perbedaan pemahaman Bahasa" }\end{array}$ \\
\hline 2 & AS & "Tidak menerapkan" & $\begin{array}{l}\text { "Toleransi saja dengan berbagai suku } \\
\text { yang ada disini" }\end{array}$ \\
\hline 3 & $\mathrm{Y}$ & "Tidak begitu menerapkan, tapi tahu" & $\begin{array}{l}\text { "Belajar berkomunikasi dengan suku- } \\
\text { suku lainnya, kalo susah ya bahasa } \\
\text { Indonesia saja" }\end{array}$ \\
\hline 4 & K & "Tetap diterapkan" & $\begin{array}{l}\text { "Menyesuaikan dengan penduduk asli, } \\
\text { terutama suku melayu, saya juga belajar } \\
\text { bahasa jawa, karena mayoritas pendatang } \\
\text { (transmigran) itu dari jawa tengah, jogja, } \\
\text { jawa timur" }\end{array}$ \\
\hline
\end{tabular}


Berdasarkan tabel di atas dapat diketahui bahwa sebagian besar informan tidak menerapkan lagi budaya asalnya, kecuali berbahasa sunda. Selain itu menurut informan penting untuk mempelajari bahasa suku-suku lain, baik itu suku asli dan atau sesama pendatang dari Pulau Jawa. Hal mtersebut dilakukan untuk menghilangkan kesalahpahaman bahasa yang seringkali memicu pertikaian di masyarakat.

\section{SIMPULAN}

Berdasarkan hasil dan pembahasan berikut ini adalah beberapa kesimpulan penelitian: Transmigran yang berasal dari jawa barat tidak semuanya mengikuti tipe transmigrasi swakarya, ada juga sebagian kecil dari mereka yang mengikuti program transmigrasi atas keinginan sendiri (umum/swakarsa).

Terdapat perbedaan lingkungan fisik yang kentara antara daerah asal transmigran dengan lokasi penempatan transmigrasi yaitu di Rasau Jaya, perbedaan-perbedaan itu meliputi; kondisi cuaca dan iklim, sumber air bersih/minum, topografi/relief/bentang lahan, serta kondisi lahan pertanian. Terdapat perbedaan budaya antara daerah asal transmigran dengan lokasi penempatan transmigrasi yaitu di Rasau Jaya, bukan hanya dengan suku asli melainkan dengan sesame pendatang/transmigran pun berbeda baik secara Bahasa, maupun kebudayaan. Dan yang terkahir transmigran asal jawa barat tidak terlalu melestarikan kebudayaan sunda, terkecuali bahasa

\section{DAFTAR PUSTAKA}

Bungin, Burhan. (2007). Penelitain Kualitatif: Komunikasi, Ekonomi, Kebijakan Publik, dan Ilmu Sosial Lainnya. Jakarta: Kencana

Edi Swasono, Sri. (1986). Sepuluh Windu Transmigrasi Di Indonesia 1905-1985. Jakarta: UIPress.

Nazir, Moh. (2005). Metode Penelitian. Jakarta: Ghalia Indonesia.

Trismi Harjanti, Diah. (2009). Faktor pendorong dan Penarik Serta Kondisi Kehidupan Sosial Para Transmigran Asal D.I Yogyakarta Di Kecamatan Rasau Jaya Kabupaten Kubu Raya Kalimantan Barat. Skripsi. Fakultas Pendidikan Ilmu Pengetahuan Sosial Universitas Pendidikan Indonesia 